\title{
The Regulating Effect of Entrepreneurial Alertness on Maker's Online Social Motivation
}

\author{
Kun Zhao ${ }^{1,2}$ \\ ${ }^{1}$ Quanzhou Normal University, Quanzhou, Fujian, China \\ ${ }^{2}$ National Academy of Economic Strategy, CASS, Beijing, China
}

\begin{abstract}
:
To explore the regulating effect of entrepreneurial alertness on the motivation of makers to use online social network. It is found that high entrepreneurial alertness can improve the sensitivity of information seeking motivation and the perception and reaction speed of external environment changes, so as to adjust the team structure and development strategy more quickly, gain competitive advantage and succeed in financing entrepreneurial projects; with high entrepreneurial alertness, makers will treat emotional motivation factors more rationally and weaken the negative effects of personal emotional motivation on financing of entrepreneurial projects. At the same time, high entrepreneurial alertness will help makers to learn forward-looking knowledge and business, and promote entrepreneurial projects to obtain leading time and fruitful innovation.
\end{abstract}

Keywords: Entrepreneurial alertness, Maker, Online social networks, Internet incubation.

\section{INTRODUCTION}

Existing research shows that entrepreneurs' personal contingency, such as entrepreneurs' ability [1], entrepreneurial network [2], entrepreneur motivation [3] and other intrinsic characteristics account for a large proportion in the investment recognition of entrepreneurial projects. In recent years, entrepreneurial alertness is a kind of ability to represent entrepreneurs' attention, perception, transmission, choice and flexibility for market opportunities. It has been widely used in the mainstream theoretical fields of entrepreneurship research, such as entrepreneurial cognitive theory and entrepreneurial action theory. Entrepreneurial alertness not 
only plays an important role in identifying and creating opportunities involving early enterprises, but also has a direct impact on strategic change decisions and organizational performance [4].

In view of this, this paper takes entrepreneurial alertness as a contingency factor, and tries to explore the driving effect of entrepreneurial alertness contingency on online social motivation on venture project financing. The arrangement of this paper is as follows: Firstly, the existing research results of entrepreneurial alertness are reviewed, and on this basis, the regulatory effect of entrepreneurial alertness on financing of entrepreneurial projects is theoretically assumed. Secondly, the variables are defined, and the entrepreneurs' data of Zhongchuang Incubation Platform is selected as the research sample. Regression analysis method is used to test the correlation assumption and quantitative analysis. The final part is conclusion and discussion.

\section{THEORETICAL BASIS AND RESEARCH ASSUMPTION}

\subsection{Entrepreneurial Alertness and Comments}

Kirzner, a famous scholar of Austrian economics school, put forward the concept of entrepreneurial alertness. It is used to describe entrepreneurs/entrepreneurs' ability to find profit opportunities in unbalanced markets with alertness and respond quickly [5].Tang and Kacmar\&Busenkz [6] developed the concept of alertness. Based on Kirzner's research results, cognitive theory and the research progress of McMullen and Shepherd, they put forward that an important component of alertness is judgment, focusing on evaluating new changes and information, and defined alertness as three different elements: scanning and searching information, connecting different information before, and evaluating whether there are profitable business opportunities. The empirical results of $\mathrm{Yu}$ et al. [7] show that alertness has a positive and important influence on the innovation of business ideas, adventure and enthusiasm. Valliere [8] pointed out that only environmental complexity and entrepreneur's self-efficacy will affect entrepreneurial alertness, and environmental complexity has a higher effect on entrepreneurial alertness than entrepreneur's self-efficacy. Roundy et al. [9] also discussed whether entrepreneurial alertness affects the decision-making related to creating and maintaining competitive advantage in the field research of organizations responding to environmental damage. Minnit [10] investigated the relative effects of alertness and asymmetric information on entrepreneurs' decision-making; Indrawati et al. [11] aims to study the influence of environmental dimension on entrepreneurial alertness, and entrepreneurial self-efficacy and its 
influence on entrepreneurs' commitment. The results show that only environmental complexity and entrepreneurs' self-efficacy will affect entrepreneurial alertness, and environmental complexity has a greater impact than entrepreneurs' self-efficacy. Therefore, the perception and response to the changing environment greatly test the dynamic ability of entrepreneurs. How entrepreneurs can find and develop opportunities with alertness, and use resources and capabilities to transform opportunities into operational and practical productivity and thus generate unique competitive advantages is very important for the growth and development of start-ups.

\subsection{Research Assumption}

\subsubsection{Regulatory effect on seeking motivation}

Seeking motivation is the initial connection and basic online social demand of maker's online social network communication. Most maker's initial online social network use motivation is to obtain information on business, management and other aspects, and to respond to market reaction in time by grasping this information. The research shows that seeking motivation is positively correlated with stability, constancy, courage, self-discipline, vigor, mental health factors and professional achievements in personality. In reality, individuals who are active in seeking information tend to give full play to their communicative advantages and have strong self-control, thus using online social networks as a platform for seeking information more, and further strengthening their motivation for seeking information. Therefore, entrepreneurs with high alertness are highly active in seeking individual information. In reality, they often give full play to their communicative advantages, and have strong self-control, making it easier to obtain financing advantages.

Based on the above analysis, this paper puts forward the following assumptions:

H1: entrepreneurial alertness can positively regulate the relationship between maker's information seeking motivation and financing of entrepreneurial projects.

\subsubsection{Regulatory effect on acquisition motivation}

(1) The regulating effect on emotion acquisition motivation 
Maker's use of online social networks is largely due to the establishment, maintenance and strengthening of daily emotions. Specifically, the entrepreneurial alertness influences the maker's emotion acquisition motivation through emotional attention allocation. When makers have high entrepreneurial alertness, they will have high emotional attention allocation, which has a high effect on their emotion acquisition motivation. On the contrary, when makers have low entrepreneurial alertness, they will have low emotional attention allocation, which has little effect on maker's emotion acquisition motivation. Considering the high alertness, makers will have a high ability of attention allocation, and can adjust their alertness relatively independently and flexibly. Makers will flexibly handle the negative effects of their emotion acquisition motivation on the financing drive of entrepreneurial projects.

Based on the above analysis, this paper puts forward the following assumptions:

$\mathrm{H} 2$ : entrepreneurial alertness has a negative regulating effect on the relationship between maker's emotion acquisition motivation and financing of entrepreneurial projects.

(2) The regulating effect on the motivation of knowledge acquisition

The concept of entrepreneurial alertness perfectly explains the differences between entrepreneurs and non-entrepreneurs in identifying opportunities, and the knowledge growth effect brought by entrepreneurs' acquired learning is the key to their ability to grasp entrepreneurial opportunities. For entrepreneurial projects, the maker needs to pay more attention to the sources of required knowledge, learn to acquire existing knowledge existing outside the project scope and internalize it, which Zahra et al. ${ }^{[12]}$ called acquisition learning. Through acquisition learning, makers and their project teams can quickly acquire the knowledge they need from various channels. Therefore, acquisition learning is indispensable for maker's entrepreneurial project, which can be measured by the cost of external knowledge learning input, and comes from maker's own learning intention and expected utility for knowledge acquisition.

Based on the above analysis, this paper puts forward the following assumptions:

H3: entrepreneurial alertness can positively regulate the relationship between maker's knowledge acquisition motivation and financing of entrepreneurial projects. 
(3) Regulating effect on business acquisition motivation

It has been pointed out that entrepreneurial alertness is positively correlated with the success rate of identifying entrepreneurial opportunities [6], so entrepreneurial alertness is positively correlated with the ability of opportunity identification [13]. The core of this idea is that the higher the alertness of entrepreneurs, the higher the probability of identifying opportunities. Opportunity identification ability is also a concrete manifestation of maker's entrepreneurial business ability.

Similarly, this paper takes the regulating effect of entrepreneurial alertness on business acquisition motivation and makes the following assumptions:

H4: entrepreneurial alertness has a positive regulating effect on the relationship between maker's business acquisition motivation and financing of entrepreneurial projects.

\subsubsection{Regulatory effect on performance motivation}

Entrepreneurial alertness plays a partial mediating role between entrepreneurs' counterfactual thinking and the recognition of entrepreneurial opportunities. The research of Minniti [10] also pointed out that high entrepreneurial alertness will lead to more entrepreneurial behaviors. Therefore, this paper argues that entrepreneurial alertness also plays a positive role in regulating performance motivation. That is, high entrepreneurial alertness will further promote the self-disclosure of makers, thus further enhancing the regulatory role in financing success of their entrepreneurial projects.

Based on the above analysis, this paper puts forward the following assumptions:

H5: Entrepreneurial alertness can positively regulate the relationship between maker's performance motivation and financing of entrepreneurial projects.

\section{RESEARCH DESIGN}

In this paper, the specific object selection, data collection methods, measurements of 
dependent variables, independent variables and control variables, and research methods are all based on previous research designs. Here, we will focus on the adjustment variable: the measurement of entrepreneurial alertness. Kaish and Gilad think that [14] the essence of alertness is to "put yourself in the information flow", and they divide entrepreneurial alertness into: Reading alertness and opening alertness. Thereafter, Ko and Butler [15] revised Kaish and Gilad's [14] entrepreneurial alertness scale, and they divided entrepreneurial alertness into two dimensions: business idea alertness and information alertness, and increased the number of questions to seven. In this study, the dimensions proposed b Ko and Butler [15] were used as measurement indicators, and the five-point Likert scoring method was used to measure the questions. Then the average scores of the sum of the business idea alertness and information alertness items of the research objects were calculated respectively, and the annual weighted average of the two dimensions in this window period was taken as assigned value of the total variables of entrepreneurial alertness of the samples.

\section{ANALYSIS AND RESULTS}

\subsection{Interactive Analysis}

Table I reports the mean, standard deviation and Pearson correlation matrix of the variables studied in this paper. Similarly, from a statistical point of view, Logit model can also test the significance of dependent variables, independent variables and control variables without requiring the measurement data of samples to have similar normal distribution. The empirical results of statistical models are often relatively stable, which can also avoid reflection problem in recognition.

Table II reports the model analysis results of binary Logit regression with robust standard error.

In Model 1, only the control variables are put into the equation. In Model 2, control variables, independent variables and related interactive items are added respectively. Among them, the interactive items in Model 2 are multiplied by the data after centralization of independent variables and regulating variables. Centralization only reduces the correlation between interactive variables and main influencing variables, and does not change the relationship between independent variables and dependent variables, so as to reduce the potential 
multicollinearity problem.

TABLE I. Mean, standard deviation and Pearson correlation matrix

\begin{tabular}{|c|c|c|c|c|c|c|c|c|c|c|}
\hline $\begin{array}{l}\text { Varia } \\
\text { ble }\end{array}$ & $\begin{array}{l}\text { Finan } \\
\text { cial_s } \\
2\end{array}$ & $\begin{array}{l}\text { Seeki } \\
\text { ng_m } \\
2\end{array}$ & $\begin{array}{l}\text { Emoti } \\
\text { onal_ } \\
02\end{array}$ & $\begin{array}{l}\text { Knowl } \\
\text { edge_o } \\
2\end{array}$ & $\begin{array}{l}\text { Busi } \\
\text { ness_ } \\
\text { o2 }\end{array}$ & $\begin{array}{l}\text { Phenot } \\
\text { ype_m } \\
2\end{array}$ & $\begin{array}{l}\text { Expe } \\
\text { rienc } \\
\text { e2 }\end{array}$ & $\begin{array}{l}\text { Siz } \\
\text { e2 }\end{array}$ & $\begin{array}{l}\text { Lo } \\
\text { ca2 }\end{array}$ & $\begin{array}{l}\text { Ale } \\
\text { rtne } \\
\text { ss }\end{array}$ \\
\hline $\begin{array}{l}\text { Financ } \\
\text { ial_s2 }\end{array}$ & 1 & & & & & & & & & \\
\hline $\begin{array}{l}\text { Seekin } \\
\text { g_m2 }\end{array}$ & $.67 * *$ & 1 & & & & & & & & \\
\hline $\begin{array}{l}\text { Emoti } \\
\text { onal_o } \\
2\end{array}$ & $\begin{array}{l}-.543 \\
* *\end{array}$ & $\begin{array}{l}-.341 \\
* *\end{array}$ & 1 & & & & & & & \\
\hline $\begin{array}{l}\text { Knowl } \\
\text { edge_o } \\
2\end{array}$ & $.61 * *$ & $\begin{array}{l}.522 * \\
*\end{array}$ & $\begin{array}{l}-.263^{*} \\
*\end{array}$ & 1 & & & & & & \\
\hline $\begin{array}{l}\text { Busine } \\
\text { ss_o2 }\end{array}$ & $\begin{array}{l}.666^{*} \\
*\end{array}$ & $\begin{array}{l}.493 * \\
*\end{array}$ & $\begin{array}{l}-.335^{*} \\
*\end{array}$ & $.782 * *$ & 1 & & & & & \\
\hline $\begin{array}{l}\text { Phenot } \\
\text { ype_m } \\
2\end{array}$ & $\begin{array}{l}-.456 \\
* *\end{array}$ & $\begin{array}{l}-.444 \\
* *\end{array}$ & $.251 * *$ & $\begin{array}{l}-.413 * \\
*\end{array}$ & $\begin{array}{l}-.192 \\
*\end{array}$ & 1 & & & & \\
\hline $\begin{array}{l}\text { Experi } \\
\text { ence2 }\end{array}$ & $\begin{array}{l}.371 * \\
*\end{array}$ & $\begin{array}{l}.346^{*} \\
*\end{array}$ & -.15 & $.45^{* * *}$ & $\begin{array}{l}.338^{*} \\
*\end{array}$ & $-.226^{*}$ & 1 & & & \\
\hline Size2 & $\begin{array}{l}.384 * \\
*\end{array}$ & $\begin{array}{l}.291 * \\
*\end{array}$ & -.103 & $.262 * *$ & $\begin{array}{l}.344 * \\
*\end{array}$ & -.046 & $\begin{array}{l}.277 * \\
*\end{array}$ & 1 & & \\
\hline Loca2 & $\begin{array}{l}.287 * \\
*\end{array}$ & $.18^{*}$ & -.063 & .14 & $.182 *$ & -.102 & .087 & $\begin{array}{l}.19 \\
3^{*}\end{array}$ & 1 & \\
\hline $\begin{array}{l}\text { Alertn } \\
\text { ess }\end{array}$ & $\begin{array}{l}.491 * \\
*\end{array}$ & $\begin{array}{l}.668^{*} \\
*\end{array}$ & $.205^{*}$ & $.657 * *$ & $\begin{array}{l}.512 * \\
*\end{array}$ & $.338^{*}$ & $\begin{array}{l}.454^{*} \\
*\end{array}$ & $\begin{array}{l}.28 \\
2^{*}\end{array}$ & $\begin{array}{l}.11 \\
3\end{array}$ & 1 \\
\hline $\mathrm{N}$ & 224 & 224 & 224 & 224 & 224 & 224 & 224 & $\begin{array}{l}22 \\
4\end{array}$ & $\begin{array}{l}22 \\
4\end{array}$ & 224 \\
\hline Avera & 0.306 & 3.451 & 3.3145 & 0.761 & 0.802 & 3.4435 & 0.161 & 0.5 & 0.2 & 3.58 \\
\hline
\end{tabular}


Article History: Received: 10 May 2021 Revised: 20 June 2021 Accepted: 18 July 2021 Publication: 31 August 2021

\begin{tabular}{l|l|l|l|l|l|l|l|l|l|l}
\hline ge & 5 & 6 & & & 6 & & 3 & 45 & 17 & 51 \\
& & & & & & & & & 7 & \\
\hline Standa & 0.462 & 1.069 & 0.7689 & 0.6158 & 0.669 & 0.9568 & 0.369 & 0.2 & 0.4 & 0.77 \\
rd & 89 & 57 & 8 & 6 & 05 & 1 & 29 & 04 & 14 & 832 \\
error & & & & & & & & 53 & 39 & \\
\hline
\end{tabular}

Note: $* \mathrm{p}<0.05, * * \mathrm{p}<0.01, * * * \mathrm{p}<0.001$. (bilateral) significant correlation. Alertness represents the variable entrepreneurial alertness.

TABLE II. Results of binary Logit regression analysis

\begin{tabular}{l|l|l}
\hline Variable & Model 1 & Model 4 \\
\hline Experience2 & $1.731^{* * *(0.554)}$ & $1.726^{* *}(0.504)$ \\
\hline Size2 & $4.002^{*}(1.229)$ & $4.081(1.602)$ \\
\hline Loca2 & $1.147 *(0.433)$ & $1.568^{*}(0.491)$ \\
\hline Alertness & $0.369^{*}(0.138)$ & $0.426^{*}(0.160)$ \\
\hline Seeking_m2*Alertness & & $1.161^{* *}(0.615)$ \\
\hline Emotional_o2*Alertness & & $-0.793^{*}(0.447)$ \\
\hline Knowledge_o2*Alertness & & $0.535^{* *}(0.123)$ \\
\hline Business_o2*Alertness & & $0.675^{* *}(0.314)$ \\
\hline Phenotype_m2*Alertness & & $0.062(0.027)$ \\
\hline $\mathrm{N}$ & 224 & 224 \\
\hline
\end{tabular}

Note: ${ }^{*} \mathrm{p}<0.05,{ }^{* *} \mathrm{p}<0.01$ and ${ }^{* * *} \mathrm{p}<0.001$. Contents in brackets are standard errors.

As far as the control variables are concerned, the regression results show that: financing experience (Experience2) has a significant positive impact on the financing success of entrepreneurial projects $(b=1.726, p<0.01)$; the region where the maker is located (Loca2) has a significant positive impact on the financing success of entrepreneurial projects $(b=1.568, p<$ 0.05); however, the team size (Size2) has no significant impact on the success of financing for entrepreneurial projects. As a regulatory variable of control, entrepreneurial alertness has a 
significant positive effect $(b=0.426, \mathrm{p}<0.05)$.

\subsection{Regression Analysis Results}

Firstly, the assumption $\mathrm{H} 1$ proposes that entrepreneurial alertness has a positive regulating effect on the relationship between information seeking motivation of makers and financing of entrepreneurial projects. The results of Model 2 show that the product of entrepreneurial alertness and seeking motivation is positively significant $(b=1.161, \mathrm{p}<0.01)$, indicating that $\mathrm{H} 1$ is supported. In order to further study the data significance of the interaction effect between variables, this paper first finds the mean value of the regulated variables, and then takes them as a group outside the area of one standard deviation around the mean value, in which those larger than the mean value + one standard deviation are regarded as the high level, while those smaller than the mean value-one standard deviation are regarded as the low level. As $\mathrm{H} 1$ proposes, when maker shows high seeking motivation on online social network, higher entrepreneurial alertness is more conducive to improving the success possibility of maker's entrepreneurship.

Secondly, assumption $\mathrm{H} 2$ puts forward that entrepreneurial alertness has a negative regulating effect on the relationship between maker's emotion acquisition motivation and financing of entrepreneurial projects. The results of model 2 show that the product of entrepreneurial alertness and emotion acquisition motivation is negatively significant $(b=-0.793$, $\mathrm{p}<0.05)$. Therefore, it also shows that $\mathrm{H} 2$ is supported. Similarly, this paper further explores the data significance of the interactive effect between entrepreneurial alertness and motivation of emotion acquisition, which further verifies the conclusion of the previous research in this paper. That is, emotion acquisition motivation is not conducive to the financing of the maker's entrepreneurial project.

Thirdly, assumptions $\mathrm{H} 3$ and $\mathrm{H} 4$ are also verified and supported by the research results of this paper. Specifically, the results of Model 2 show that the product of entrepreneurial alertness and Knowledge_o2 is positively significant $(\mathrm{b}=0.535, \mathrm{P}<0.01)$. The product of entrepreneurial alertness and Business_o2 is positively significant $(b=0.675, \mathrm{p}<0.01)$. When maker shows high knowledge acquisition motivation and business acquisition motivation through online social network, higher entrepreneurial alertness is more conducive to the success of maker's entrepreneurial project financing, which fully shows that entrepreneurial alertness plays a better role in regulating both knowledge acquisition motivation and business acquisition motivation. 
At last, assumption $\mathrm{H} 5$ puts forward that entrepreneurial alertness has a positive regulating effect on the relationship between maker's motivation and financing of entrepreneurial projects. However, the results of model 2 show that the product of entrepreneurial alertness and performance motivation (Phenotype_m2) does not reach a significant level, indicating that assumption H5 is not supported.

\section{CONCLUSION AND DISCUSSION}

The main results of this study show that entrepreneurial alertness plays an interactive role in regulating the online social motivation of some makers and the financing of entrepreneurial projects. Specifically, high entrepreneurial alertness is conducive to improving the sensitivity of information seeking motivation and the perception and respond speed of changes in the external environment. With high entrepreneurial alertness, makers can adjust the team structure and development strategy more quickly, gain competitive advantage and succeed in financing entrepreneurial projects; with high entrepreneurial alertness, makers will treat emotional motivation factors more rationally and strengthen the advantages of entrepreneurial projects, thus helping to weaken the negative effects of personal emotional motivation on financing of entrepreneurial projects. At the same time, high entrepreneurial alertness will also assist maker in forward-looking knowledge learning and business, further promote makers to obtain key social resources such as product research and development and product listing, and promote entrepreneurial projects to obtain leading time and fruitful innovation.

The theoretical innovation of this paper mainly includes the following two aspects:

First, in this paper, entrepreneurs' awareness is taken as the starting point, and insights are

provided for star-ups from the perspective of entrepreneurs' perception ${ }^{[16-18]}$, which provides a more meaningful basis for makers to better grasp market opportunities and investment opportunities, and then adjust the driving force of venture financing.

Secondly, through empirical analysis, this paper examines how entrepreneurial alertness can adjust the financing of entrepreneurial projects driven by online social motivation, which complies with the call of academia for research on financing strategy selection of entrepreneurial projects [19-20], and further enriches the research framework of entrepreneurial financing. 
Of course, since this paper adopts a large sample empirical method to study the research problems, it is difficult to avoid the defects in static analysis of secondary data. Therefore, regarding how entrepreneurial alertness dynamically adjusting online social motivation drives venture financing of makers, qualitative research can be conducted in the future by means of cross-case long-span time tracking to give more accurate answers.

\section{ACKNOWLEDGEMENTS}

Project supported by China Postdoctoral Science Foundation "Research on driving mechanism and innovation performance of mass Entrepreneurship Model of production enterprises" (2020m671926); Fujian middle-aged and young teachers' education and scientific research project "Research on Internet collaborative application of production enterprises under enterprise led mass Entrepreneurship Model" (jas19253).

\section{REFERENCES}

[1] Lee Y S, Eesley C (2018) The persistence of entrepreneurship and innovative immigrants. Research Policy 47(6):1032-1044

[2] Lee H S (2017) Peer networks in venture capital. Journal of Empirical Finance 41:19-30

[3] Ahunov M, Yusupov N (2017) Risk attitudes and entrepreneurial motivations: Evidence from transition economies. Economics Letters 160(Issue undefined):7-11

[4] Philip, Roundy T, David, Harrison A, Susanna Khavul, Liliana Pérez-Nordtvedt and Jeffrey E McGee (2017) Entrepreneurial alertness as a pathway to strategic decisions and organizational performance. Strategic Organization 16(2):192-226

[5] Kirzner M (1980) Perception, opportunity and profit: Studies in the Theory of Entrepreneurship. Chicago: The University of Chicago Press

[6] Tang J T, Kacmar K M, Busenitz L (2012) Entrepreneurial alertness in the pursuit of new opportunities. Journal of Business Venturing 27(1):77-94.

[7] Yu C, Xiao H (2016) How to become an excellent entrepreneur: The regulating effect of risk propensity on alertness to business ideas and entrepreneurial capabilities. Technological Forecasting \& Social Change (112): 171-177

[8] Valliere D (2015) An Effectuation Measure of Entrepreneurial Intent. Procedia-Social and Behavioral Sciences (169):131-142

[9] Roundy P T, Bradshaw M, Brockman B K (2018) The emergence of entrepreneurial ecosystems: A complex adaptive systems approach. Journal of Business Research (86):1-10

[10] Minniti M (2004) Entrepreneurial alertness and asymmetric information in a spin-glass model. Journal of Business Venturing 19(5):637-658 
[11] Indrawati N K, Salim U, Djumahir (2015) Moderation Effects of Entrepreneurial Self-efficacy in Relation between Environmental Dimensions and Entrepreneurial Alertness and the Effect on Entrepreneurial Commitment. Procedia-Social and Behavioral Sciences (169):13-22

[12] Zahra S A, Nielsen A P, Bogner W C (1999) Corporate Entrepreneurship, Knowledge and Competence Development. Entrepreneurship Theory and Practice 23(3):169-189

[13] Song G, Min S, Lee S, Seo Y (2017) The effects of network reliance on opportunity recognition: A moderated mediation model of knowledge acquisition and entrepreneurial orientation. Technological Forecasting and Social Change (117):98-107

[14] Kaish S, Gilad B (1991) Characteristics of opportunities search of entrepreneurs versus executives: Resources, interest and general alertness. Journal of Business Venturing 6(1):45-61

[15] Ko S, Butler J E (2003) Alertness, bisociative thinking ability, and discovery of entrepreneurial opportunities in Asian hi tech firms. Wellesley, MA: Babson College. http://www.babson.edu/entrep/fer/BABSON2003/XVI/XVI-P3/XVl-P3. htm

[16] Obschonka M, Hahn E, Bajwa N U H (2018) Personal agency in newly arrived refugees: The role of personality, entrepreneurial cognitions and intentions, and career adaptability. Journal of Vocational Behavior (105):173-184

[17] Stroe S, Parida V, Wincent J (2018) Effectuation or causation: An fsQCA analysis of entrepreneurial passion, risk perception, and self-efficacy. Journal of Business Research (89):265-272

[18] Zhu Z, Lin S F (2019) Understanding entrepreneurial perceptions in the pursuit of emerging e-business opportunities: The dimensions and drivers. Computers in Human Behavior (95):252-261

[19] Galloway T L, Miller D R, Sahaym A, Arthurs J D (2017) Exploring the innovation strategies of young firms: Corporate venture capital and venture capital impact on alliance innovation strategy. Journal of Business Research (71):55-65

[20] Cumming D, Deloof M, Manigart S, Wright M (2019) New directions in entrepreneurial finance. Journal of Banking and Finance (100):252-260 